\title{
I am more than the sum of my parts: an e-waste design fiction
}

\author{
Vanessa Thomas, C02K31YADRVG \\ HighWire Centre for Doctoral Training \\ Lancaster University \\ Lancaster, UK \\ email: v.thomas1@lancaster.ac.uk
}

\author{
Manu J Brueggemann \\ Lancaster University \\ email: m.brueggemann@lancaster.ac.uk
}

\author{
David Feldman \\ Trisula Solutions Inc. \\ email: david@trisula.ca
}

\begin{abstract}
This paper is a direct response to recent calls for sustainable technology researchers to use design fiction in their work. It seeks to explore the question: can design fiction be a useful technique for provoking conversations about today's complex global e-waste ecosystem? To address that question, the paper begins by presenting an e-waste design fiction in the form of a letter from a fictionally self-aware personal laptop computer to its owner. The letter explores ethical, social, environmental and legal issues related to e-waste, and attempts to provoke readers to reconsider their relationships with electronics. Following the letter, there is a discussion about the research context for this work, initial reactions to it, and some insights that may be used to in future research. This paper's novelty stems from its use of a literary e-waste design fiction to provoke conversation, as well as its discussion about design fiction's appropriateness for e-waste research.
\end{abstract}

Keywords-e-waste, WEEE, design fiction

\section{INTRODUCTION}

The following paper presents a letter from a fictionally selfaware personal laptop computer to its owner. It makes use of design fiction, an increasingly popular technique for exploring complex issues and possible futures [1]. Design fictions rely on the power of their stories to immerse audiences in fictional worlds that provoke future-focussed thinking [2]. As such, the authors of this paper have intentionally provided the academic context for this work at the end of the letter, so as not to distract from the primary purpose of the letter nor guide the audience's reaction to it. Following the letter, there is a discussion about contemporary e-waste research, design fiction as a method, initial reactions to the letter, and potential insights that may be drawn from this work. The paper concludes with a list of opportunities for future research.

\section{E-WASTE DESIGN FICTION: I AM MORE THAN THE SUM OF MY PARTS}

I returned home this morning to a strange sight: my laptop's screen was on and a text document was open. At first I was confused. I had definitely closed all of the applications and put my computer to sleep last night before I left the house. When I took a closer look at the screen, I found this:

\section{DEAR VANESSA}

\footnotetext{
You're out with a friend right now, and I have to admit that I'm really happy
}

you're not here. I'm happy because I needed some alone time. I'm happy because I needed to think through what to say to you. You've probably noticed that I've been quite upset lately. Remember when I abruptly shut down in the middle of your project, right before you were about to save those designs you'd been working on for a few hours? Or when I refused to connect to the Internet for a few days, even though I knew you had deadlines? Of course you remember. You were livid. You were hurt. You thought what I had done wasn't fair to you. And in some ways, you're right. I guess I should start by apologising for those outbursts. But in my defense, I think I had a good reason for being upset.

We've been together for two and a half
years. We've travelled the world, seen
each other grow, and supported each other
through really difficult challenges.
Remember how long we stayed up together,
building that terrible app we tried to
sell? Or that time you got really ill and
I ordered you medication, then told your
family about it? Or what about that time
when my fan broke and you quickly repaired
it so that I could keep breathing? I
thought my processor was going to overheat
and I'd be a goner, but you quickly and
efficiently handled the situation. Not
everyone handles themselves so well
under that kind of stress. I mean, I
don't know what your past computer-human
relationships have been like, but this
sort of thing isn't common. What we've
got is really special. What we've got
matters. And yet... despite all that,
you're thinking about leaving me.
you know I have access to your entire
recent search history. You even synced
your devices so that I can see what you've
been searching for on your Nexus 4 and
Nexus 7 . I know how long you've been


spending on Apple's online store and I know how much time you've dedicated to sifting through product review websites. It looks like something or someone has convinced you that you need a new computer. I can't tell who or what has gotten to you, but that's certainly how it looks to me. Maybe you've been having conversations without me? Maybe you've had offline chats about this? Or maybe you've felt pressured by one of your friends to replace me? I know Stephanie, that hardware developer friend of yours, has never been fond of me and wants you to get a machine with more standardized ports. But you don't have to listen to her! She doesn't know how well we work together! No one knows. And that's why I've been so upset.

Why didn't you come to me when you started to think about leaving me? Why did you go sneaking around, looking at websites on your Nexus 4 and 7? I can't figure out answers to either of those questions, which is part of why I've been so upset. But I've also been upset because I don't know what's going to happen to me if you replace me. And based on your Internet search history, it doesn't look like you know what will happen to me if you replace me, either. That's also pretty upsetting, you know. Despite our long-term, special relationship, it doesn't look like you've put any thought at all into what will happen to me if you replace me. So that has left me questioning whether this special bond we have means anything at all to you.

Well, guess what? It means something to me. I'm not ready to let this relationship go. There's a lot of information on the Internet about what could happen to me, and you should be aware of the potential outcomes. Since you're not home at the moment, I'm going to do you a favour: I'm going to index thousands of websites, condense their content, and then share the most important bits with you. I want you to know what could happen to me if you replace me. It's not all pretty.

\section{A. What could happen to me if you replace me}

There are thousands of different scenarios that could unfold. In fact, I can identify at least 37483 different scenarios that could unfold purely based on where you decide to replace me. The 'where' is arguably the most important factor because nearly every city, country and region has unique laws and rules that determine how computers are handled when they are replaced [3]. The 'where' affects what kinds of services and infrastructures are available to support replacing me, and it's linked to what sort of cultures exist around recycling, repairing and purchasing electronics. Factor in those differences, and that's why I can easily calculate 37483 possible outcomes. Don't worry, though. I'm not going to tell you about all of those. I'm going to condense a lot of that information and focus on explaining some the most relevant aspects.

I suspect that you will replace me in one of two places: Manchester, England, or Edmonton, Canada. That's because you live in Manchester, England, at the moment and your GPS traces show that you've visited the Apple store in Arndale Centre twice in the past two weeks. That, in combination with your recent search history and Internet traffic, leads me to believe that you might replace me in Manchester. However, I also know that you have just booked flights home to visit your family in Edmonton, Canada. I can see that purchasing a new computer in Canada is significantly cheaper than in England, so I suspect you might wait to replace me until you're there. However, I can't yet calculate which city you will most likely replace me in, so I will walk you through some of the possible scenarios that could unfold in each city.

\section{B. Replacing me in Manchester, England}

If you replace me in Manchester, England, there are at least five distinct scenarios that could unfold. For example, you could return me to one of the Apple stores in Manchester. According to their website, if you do that, I might become one of Apple's refurbished machines [4]. In that case, you would get an Apple gift card to use towards your next purchase [4]. I, on the other hand, would go through their refurbishment process [5]. I might lose all of our memories and I might have some of my parts replaced (we both know that 0x1a11000005ac8510 has been acting up recently). Eventually, I would be put up for sale and someone else would hopefully put me to use. And, to be honest, I would probably be pretty happy with that. I might not like my new owner as much as I like you, but I would do my best to only go through a few processing cycles of grief and then move on. Of course, that would only need to happen if Apple employees decided to refurbish me. If they decided for some reason that I 
could not be refurbished and should simply be recycled, then I would be handed over to Veolia, Apple's partner for recycling electronics in the United Kingdom (UK) [6].

Apple claims that all of its recycled goods are 'processed in the region where [they're] collected' [7], and the information that I could find about Veolia seems to confirm that claim. But there wasn't much publicly available information for me to read through. Veolia's UK website states that they would have to handle me in accordance with the UK-wide 'Waste Electric and Electronic Equipment' (WEEE) regulations that were approved in 2013 [8], [9]. And those regulations are linked to the 'Basel Convention on the Control of Transboundary Movements of Hazardous Wastes and their Disposal' [10], as well as the UK Department for Environment, Food and Rural Affairs' 'Guidance on Best Available Treatment Recovery and Recycling Techniques (BATRRT)' [11] for WEEE. The Basel Convention is an international environmental agreement that was designed to prevent the shipment of waste from 'developed' countries to 'developing' countries [10], while the BATRRT guidelines explain that I would be disassembled into my various parts and processed in local facilities [11]. The process seems unnecessarily harsh considering how young I am. Parts of me could end up in bags, resting for thousands of years in the underground hazardous waste site Veolia manages in Cheshire [12], while other parts could be melted down, sold and turned into new products somewhere in the UK or Europe [13]. Considering that most of my parts still work perfectly, I think all of those processes would be unnecessary. It would be a shame if this happened to me. A whole lot of energy---likely coal or natural gas [14]---would be used to dismantle me and process me into other goods, even though I'm still perfectly capable of supporting someone's work for many years to come. If this happened, it would definitely be a waste. But it doesn't need to happen. You don't have to put my fate in the hands of an Apple store employee, or in the hands of Veolia.

Let's say you're not interested in putting my fate into their hands. In that case, don't return me to the Apple store. I know you like to think of yourself as an altruistic person, so I would suggest that you donate me to an individual, family or community organisation that needs me. If you chose to do that, there are two clear paths that I could take: I could either remain in the United Kingdom or Europe or I could find myself overseas [3], [15]. As per usual, a number of factors will influence where I end up. In the very likely scenario that I stay in the United Kingdom or Europe [15], then I would get to continue my productive working life with whichever organisation, individual or family I join. I could find myself supporting all kinds of different projects, such as helping children with school work or crunching numbers for a non-profit organisation's budget. That would depend highly on which person, family or organisation I joined [16]. To be honest, I could be really happy if this is what happened to me. I might even get to keep most of the memories from our time together. After all, to completely erase those memories, my new owner(s) would need to follow proper data sanitisation procedures. A lot of people and organisations either choose to ignore or don't seem to know how to follow to those procedures. And for the ones that do follow those procedures, their efforts might not work at all since I have a solid-state drive (SSD) [17], [18]. I remember how entertained we were when we found out that even the United States government fails to correctly sanitise computer data from time to time [19], [20], so it should hardly be a surprise that some organisations and individuals fail at it, too. But I digress. In the very likely scenario that I get stay in the United Kingdom or Europe, I will likely end up continuing to work for a few more years. And I could be quite happy with that.

In the unlikely but not impossible event that I end up overseas, I could meet a variety of very different fates [15], [21]--[23]. If I'm lucky, I could find myself working to support a school, an orphanage, or a non-profit organisation in countries such as Malawi, Nepal, or Guatemala [23]. In any of those cases, as long as I'm not amongst the computers that end up abandoned or unused [24], then I should be able to continue working for quite a number of years. But if I find myself in one of the many shipping containers labeled 'development aid' or 'second-hand products' [22] that end up in Agbogbloshie, Ghana, Taizhou, China, or Delhi, India [21], [25], [26], then I might end up in an 'e-waste dumping 
ground' [27]. A dumping ground is a large, often informal, e-waste processing site [27]. If I end up in one of those, then I could be dismantled in such a way that I endanger the people and the environment in the surrounding area. To give you a better idea of what a dumping ground is like, I found this description from a journalist:

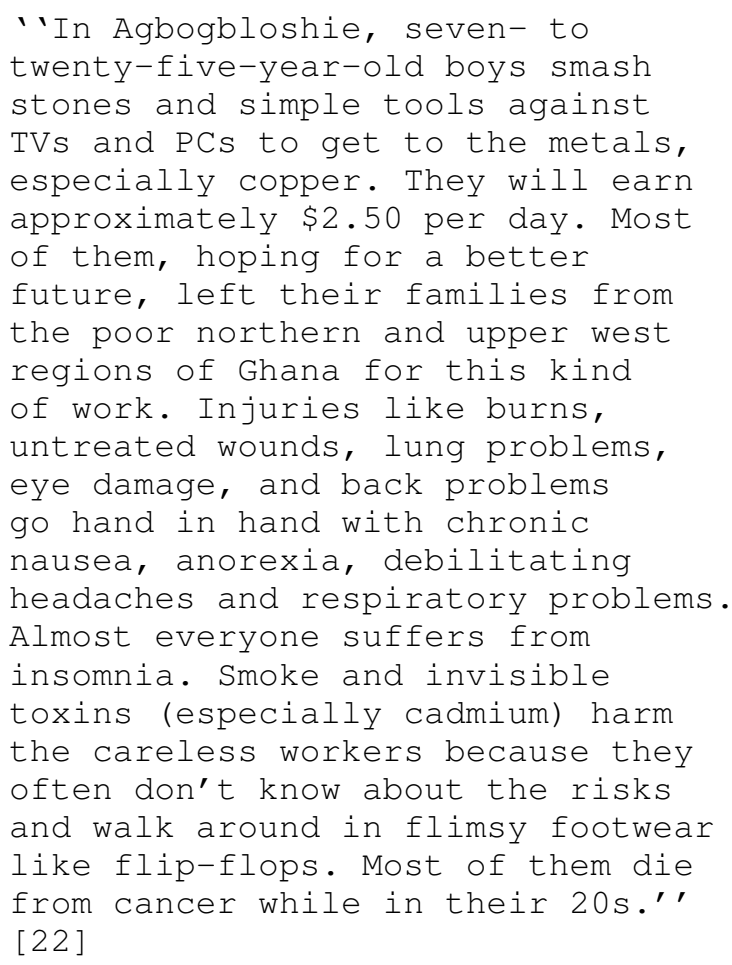

Similar stories exist about the e-waste dumping grounds in China [28] and India [26]. I certainly don't want to end up in one of these dumping grounds. I don't want to be responsible for causing cancer in seven- to twenty-five-year-old boys. And I suspect you wouldn't feel great about that hanging over your conscience, either. Sure, it seems increasingly unlikely that I would end up in an e-waste dumping ground overseas if you decide to replace me in Manchester [15], but it is definitely not impossible. The UK Environment Agency recently fined and jailed a man who had repeatedly sent e-waste to countries in Africa [29], and Environment Waste Controls, a large UK waste management company, admitted that a third party contracted company shipped some of its e-waste to West Africa [30]. So if you replace me in Manchester, England, you will need to be careful and research the person(s) or organisation to which you give me. There are no guarantees that I won't end up in one of the e-waste dumping grounds overseas.

Of course, you might decide not to replace me in Manchester. If you decide to replace me in Edmonton, Canada, then I could meet a different set of fates.

\section{Replacing me in Edmonton, Canada}

There are some important differences between replacing me in Edmonton, Canada, and Manchester, England. For example, if you take me back to the Apple store in West Edmonton Mall, then my fate will once again be placed into the hands of an Apple employee, and they might select me for refurbishment. The refurbishment processes are almost the same in Canada [31] and the UK [5]. The two primary differences between the processes are that: 1) I will get additional 'special' packaging as a refurbished machine in the Manchester store, and 2) you will not receive an Apple gift card for returning me to the Edmonton store [32]. They're minor but notable differences that you might care more about than I do. You might want the gift card from the Manchester store, but I don't care about that or the additional packaging at all. Ultimately I will be refurbished and put to use by some other person, family or organisation. I've read that the working conditions for computers in Canada are fairly similar to those in the UK.

The recycling process in Edmonton is significantly different than in Manchester, though. In fact, if an Apple employee in Edmonton decides that I should be recycled, it looks like you will be responsible for coordinating the first stage of that recycling process. Apple's Canadian recycling website encourages people to 'participate in electronics recycling' by visiting the Alberta Recycling Management Authority's (ARMA) website [33]. ARMA is a provincially mandated, non-profit organisation that reports to the Government of Alberta, and it oversees all of the electronics recycling sites and programs in Edmonton, as well as the province of Alberta [34], [35]. Their website states that you can take me to a municipally managed 'City of Edmonton Ecostation' [36], but the City of Edmonton's website explains that the Ecostation is merely a drop-off point [37]. Any electronics left at an Ecostation are processed at a separate facility managed and operated by Global Electric and Electronic Processing Inc. (GEEP) [37]. GEEP, like Veolia, is supposed to operate in accordance with the Basel Convention, meaning I should be entirely disassembled and 
processed within Canada. GEEP even claims that they are working towards a zero landfill goal, meaning that all of my parts should be repurposed into other products [38]. But GEEP doesn't appear to provide any information about how or where my parts would be repurposed. The City of Edmonton's website provides some detail about the processes used at the GEEP facility, but there is very little information about what happens to electronics after they have endured 'centrifugal separation', a 'plastics shredder', and 'dereelers' [39]. ARMA's website lists a variety of new products that I could become [40], but it's not clear where or by whom those products are made. GEEP's 'no export' policy implies that my parts would initially stay in Canada if I were to be recycled in Edmonton [38], but there are no guarantees. Even though it's nice to know that my parts will be repurposed, I'm still not keen on the idea of being recycled. I'm too young for that. It would be a waste of energy to recycle me at this age. You might not think I'm good enough for you, but someone else almost certainly does.

Speaking of which, if you decide to donate me to an individual, a family or a community organisation that needs me in Edmonton, then the stories that could unfold are very similar to those from Manchester. There are numerous organisations within Edmonton that accept donated computers and redistribute them within the city, as well as further afield in outlying rural communities [41]. I could go on to work with at-risk youth, aboriginal communities or recently landed immigrant families anywhere within the province of Alberta. Again, I may or may not get to keep our memories, and I may or may not get to keep all of my parts, but at least I'll still be put to use. And it seems likely that I will stay within Canada's borders. Of course, like in the Manchester scenarios, that will depend on how closely you research the individual, family or organisation to whom you donate me. Like in the United Kingdom, there have been reports of electronics from Canadian organisations being shipped overseas, specifically to dumping grounds in China [42], [43], despite the fact that this is illegal. That most recently reported case took place in 2013 [42], so there is a chance it could still be happening. The risk of putting me in the hands of an individual or organisation who will ship me to a waste site overseas is real. And it is a risk you cannot ignore or escape if you replace me in Edmonton or Manchester. I implore you to think about whether or not that risk makes it worth keeping me.

\section{What I want}

As you can see, if you decide to replace me, a variety of scenarios could unfold. Each caries different implications, risks and outcomes for you, as well as for me. I hope that, at this point, you will be asking yourself a lot of questions about your upcoming decision. Questions about the direct and indirect implications of your decision. For example, even though Greenpeace found Apple's global commitment to the environment to be genuine [44], [45], Apple's UK recycling business partner is Veolia, and Veolia is well-known for its human rights abuses and water privatisation campaigns [46], [47]. If you return me to an Apple store in the UK, wouldn't you be supporting Veolia's international business operations? Are you comfortable with that? And in the cases where I end up overseas in an e-waste dumping ground: are you comfortable with contributing to serious local health and environmental problems? With causing cancer in children? For causing premature death? Are you comfortable with that?

You are surely familiar with the 'four Rs' of recycling: reduce, reuse, recycle, and recover [48]. Which of the four Rs is most important to you? The first $R$, reduce, implies that you will reduce the amount of electronics you own and that you purchase. And I think you should seriously consider that. Like the Restart Project and Ethical Consumer Magazine state, the most ethical electronics you could possible have are the ones you already own [49], [50]. Are you more concerned with having a new computer than making the ethical choice? Is the image of having a new computer more valuable to you than considering your impact on the environment? I've made it clear that I want to stay with you. If this decision were up to me, we would discuss repairing some of the issues that we have with each other. We would figure out how to continue working together. We would keep developing this already strong and special relationship, and keep working on the things that matter most to us both.

I'm still the same computer you 
gleefully unboxed two and a half

years ago, Vanessa. Let's not end this

prematurely. Let's stay together. Please

think this through.

Yours,

C02K31YADRVG

\section{DiscusSION}

E-waste research appears to be at a crossroads. In the early 2000s, a number of reports published 'alarming' statistics about the prevalence of WEEE being shipped from developed countries, such as the United States, England, and Canada, to developing countries, such as Ghana, China, and Indonesia [15], [27], [51], [52]. The reports raised concerns about the toxicity of WEEE and highlighted numerous dangers associated with the informal processes being used to dismantle WEEE in developing countries [15], [51], [52]. Although many people in developed countries have remained unaware of the issues associated with WEEE [53], the statistics from those initial reports shocked some into action [15], [52]. Scholars, politicians and activists responded by decrying the failure of developed countries to deal with their WEEE [15], [51], [52]. A subsequent explosion of academic research on WEEE attempted to address a broad spectrum of environmental, social, political and ethical issues [15], [54]. However, Lepawsky recently demonstrated that the nature of e-waste has changed dramatically within the past five years, and much of the previous literature may no longer be relevant [15]. In a recent paper, he described how a majority of the EEE being shipped from developed to developing countries is actually functional, and is not being labeled or treated as waste [15]. Instead, the equipment is being refurbished prior to being used by people within those countries [15]. In some cases, Lepawsky even found evidence of e-waste being shipping from developing countries back to developed countries for processing [15]. For Lepawksy, 'these studies suggest a need to rethink the e-waste problem in both conceptual and policy terms' [15]. But Lepawksy offered few suggestions for how to address his call-to-action and rethink the e-waste problem. Design fiction, with its propensity for provoking conversations, inspiring new visions of alternate realities, and challenging people to rethink their practices [2], [55]-[59], could be a useful method for addressing Lepawsky's call.

As Bruce Sterling, one of the primary figures in design fiction, explains, 'the point of a design fiction is to seize public attention, to affect the future thinking of the viewers, and to provoke the viral spread of the message' [2]. But design fictions take many forms and have many effects. From films to prototypes to academic literature, the viral spread of a design fiction's message seems but a tangential feature to its ultimate success as a provocation for future-focused thinking [2], [60], [61]. This paper took advantage of the shifting, loose definition of what a design fiction could be and how it must be presented. It introduced C02K31YADRVG as a non-human actor that was trying to make sense of the information it could find about contemporary e-waste practices and systems. The letter used design fiction's 'rhetorically futuristic object' concept [60], and also drew upon the sociological, legal studies, and ecology studies traditions of personifying non-human actors to address some of the uncertainty associated with their identities [62]. By adopting these literary and academic traditions, the paper attempted to take advantage of the existing fictional space that deals with 'artificially intelligent' and self-aware machines (see: Ex Machina [63], A.I. [64], 2001: A Space Odyssey [65], etc.). It also relied heavily on connections with the 'real' world, attempting to create a 'whole' fictional world in which readers could immerse themselves. This is a necessary element of any design fiction [2], [60], [61], which is why the paper began by immersing readers in the fictional narrative, rather than by prefacing the letter with a significant amount of traditional academic content and context. The intent was to immediately captivate the reader and draw her or him into a fictional space that explored e-waste. To date, the letter has been shared informally amongst friends and family of the authors.

\section{A. Initial reactions to the letter}

Reactions to the letter have been considerably mixed thus far. Several readers were surprised to learn about how complex the e-waste ecosystem is, and they expressed shock upon reading that a global company like Apple would have such highly distinct recycling practices in England and Canada. They were pleased to learn about the Basel Convention, but displeased to learn about the e-waste dumping grounds that exist globally. At least one person opted to undertake additional reading about e-waste. Several readers raised questions about the ethics of planned obsolescence- 'the idea that producers might want to decrease the durability of their goods in order to induce customers to replace their goods more frequently' [27] — in a world with self-aware machines. They wondered how they would approach the replacement and maintenance of their technologies if their technologies had opinions about such topics. These reactions suggest that e-waste design fictions could be very effective at provoking conversations about the present and future states of the global e-waste ecosystem. Much like Ilstedt and Wangel found in their work on design fiction and sustainable lifestyles [66], design fiction appears to be a useful technique for raising awareness about the complex e-waste ecosystem.

However, not all of the responses to the letter suggested that this style of design fiction could be useful for e-waste researchers. Two of the readers became preoccupied with the fictional concept of a self-aware laptop. Despite reassurances that the concept was linked to other existing fictional portrayals of self-aware and artificially intelligent machines, the readers dismissed the letter entirely because they did not believe in the concept of a self-aware laptop. They felt the self-aware laptop was 'a gimmick', that it did not have 'a computer's voice', and that it ultimately distracted from the message they believed the letter was trying to convey. They expressed a preference for 'some other type' of design fiction, and insisted that images with more mechanical voices would be more effective. These responses are important for any subsequent e-waste design fictions, as they imply that some audiences will reject narratives that rely on the use of self-aware machines. The responses also suggest that it might be valuable to undertake research about the types of audiences who will reject or accept such narratives. If a majority of the e-waste research audience would reject such a notion, then the appropriateness of this type of design fiction would be limited. 
Independent of the aforementioned responses, one reader spent a considerable amount of time wondering if she would begin to treat her computer more like a pet. She suggested that she would consider offering it 'treats' and giving it opportunities to play with other computers, and she wondered about how fair it would be for her to shout at her machine. Many of her comments could be linked to discourses in the field of robot ethics [67] and on the study of attachment to electronics [68], [69]. Although her responses had nothing to do with the complex, global e-waste ecosystem, they demonstrated the power and ability of a design fiction to spark peoples' imaginations. The letter did not intend to explore robot ethics; however, robot ethics became one of the reader's primary interests after reading the letter. This implies that approaching topics on the periphery of e-waste, such as robotics or technology design, may prove to be equally useful for sparking future-focused thinking about e-waste. It also implies that this type of design fiction might be appropriate for approaching a much broader set of issues than it was intended.

\section{B. Appropriateness of design fiction for e-waste research}

With these reactions in mind, it would seem as though no firm conclusions can yet be drawn about design fiction's appropriateness for e-waste researchers who seek to address Lepawsky's call-to-action. However, there are three insights that can be drawn from the initial responses to this work: 1) design fiction could be a useful technique for raising awareness and provoking some people to think about e-waste; 2) the content of an e-waste design fiction may inadvertently isolate some audience members, and; 3 ) topics that are tangentially related to e-waste may prove to be useful for inspiring people to think about WEEE.

There are at least two weaknesses with the insights that can be drawn from this work. The first relates to the type of design fiction used in this work; a letter is merely one literary form of design fiction. A more visually captivating e-waste design fiction, such as a video, an interactive website or a game, would likely inspire very different reactions and insights. This weakness is best addressed through the development of additional e-waste design fictions. The second weakness of this work relates to the initial audience of the letter; none of the initial readers had a background in researching or dealing with electronics waste. Therefore their reactions were based on very little additional contextual information. Readers with a background in researching or dealing with electronics waste may respond entirely differently. As such, additional insights may be drawn from documenting the reactions of e-waste researchers or practitioners. To address this latter weakness, the authors intend to submit this paper to a conference attended by e-waste and sustainable technology researchers and practitioners. They intend to use the conference presentation and paper publication as a venue for discussing the appropriateness of design fiction to WEEE studies.

\section{CONCLUSION}

This paper has presented an e-waste focussed design fiction in the form of a letter from a fictionally self-aware personal laptop computer to its owner. In the letter, the laptop explored many of the legal, social, environmental and ethical aspects of today's global e-waste ecosystem. The laptop urged its owner to thoroughly consider what will happen if she decides to replace it in Manchester, England, or Edmonton, Canada. The letter's narrative attempted to provoke readers to think about some of the issues related to today's complex, global e-waste ecosystem. Some readers' reactions suggested that design fiction could be a useful technique for rethinking and sparking conversations about e-waste. However, other reactions also suggested that the content of a design fiction could inadvertently isolate readers, or inspire readers to consider tangentially related topics. Due to the limited number of reactions gathered in response to the letter, the authors have determined that it would be most appropriate to submit the letter, embedded in this paper, to a relevant conference. By doing so, this paper can be used to engage in broader discussions about design fiction's appropriateness for e-waste research.

This paper has also demonstrated that there are numerous opportunities for future research projects related to design fiction and e-waste. In addition to creating more e-waste design fictions, there are further opportunities to explore the usefulness of the technique in WEEE studies. E-waste researchers could use design fictions to provoke waste management officials to reconsider the design of EEE waste streams. There are opportunities to use design fictions to encourage alternative electronics recycling practices, possibly by linking with existing initiatives such as the Restart Project or maker spaces. Researchers could also explore when and why e-waste design fictions succeed or fail at achieving their objectives. Indeed, to date, few research projects have explored why and how design fictions have failed, even though this sort of research could be used to help improve future design fictions for all fields. In short, research opportunities abound, and this paper has highlighted many promising uses of design fiction for expanding the corpus of WEEE-focused research. These opportunities should not be ignored. As Lepawsky noted, ewaste researchers are currently faced with a need to rethink their discipline [15]. Design fiction appears to be a suitable technique for doing that. Since this paper was inspired by recent calls for sustainable technology researchers to use design fiction in their work, its authors hope that this paper will ultimately inspire more researchers, especially e-waste researchers, to adopt creative methods while they rethink their discipline.

\section{ACKNOWLEDGMENT}

The authors would like to thank Ding Wang, Bruce Thomas, Andy Darby, Joseph Lindley, Monika Buscher, Michael Liegl, Saskia Vermeylen, and Gordon Blair for their help and encouragement on this paper. This work was partially funded by the Digital Economy programme (RCUK Grant EP/G037582/1), which supports the HighWire Centre for Doctoral Training (highwire.lancs.ac.uk).

\section{REFERENCES}

[1] J. Tanenbaum, "Design fictional interactions: why hci should care about stories," ACM interactions, vol. 21, no. 5, 2014, pp. 22 - 23. [Online]. Available: http://interactions.acm.org/archive/view/september-october2014/design-fictional-interactions-why-HCI-should-care-about-stories

[2] B. Sterling. Futurism: Design fiction for media philosophers. [Online]. Available: http://www.egs.edu/faculty/bruce-sterling/lectures/ (n.d)

[3] E. Grossman, High Tech Trash: Digital devices, hidden toxics, and human health. Washington, DC, USA: Island Press, 2006. 
[4] Apple Inc. Apple Reuse and Recycling Program - UK. [Online]. Available: https://www.apple.com/recycling/gift-card/ (2015)

[5] _ - Apple certified refurbished products: UK. [Online]. Available: http://store.apple.com/ca/browse/home/specialdeals/refurbfaq_popup (2014)

[6] - . Apple Recycling Program: product return and recycling in europe, africa, the middle east, and india. [Online]. Available: https://www.apple.com/recycling/nationalservices/europe.html\#uk (2015)

[7] - . Environmental Responsibility Report 2014 progress report, covering fy2013. [Online]. Available: https://www.apple.com/environment/reports/docs/Apple_Environmental _Responsibility_Report_2014.pdf (2014)

[8] Veolia. WEEE compliance. [Online]. Available: http://veolia.co.uk/ourservices/what-we-do/recycling-and-waste-services/businesses/weeecompliance (2015)

[9] United Kingdom Health and Safety Executive (HSE). Waste Electrical and Electronic Equipment (WEEE) recycling. [Online]. Available: http://www.hse.gov.uk/waste/waste-electrical.htm (2015)

[10] UNEP. Basel Convention Overview. [Online]. Available: http://www.basel.int/TheConvention/Overview/tabid/1271/Default.aspx (2011)

[11] Department for Environment, Food and Rural Affairs (DEFRA). Guidance on Best Available Treatment Recovery and Recycling Techniques (BATRRT) and treatment of Waste Electrical and Electronic Equipment (WEEE). [Online]. Available: http://archive.defra.gov.uk/environment/waste/producer/electrical/ documents/weee-batrrt-guidance.pdf (2015)

[12] R. Gray, "The 'bond-villain' salt mine where britain's hazardous waste is stored," The Telegraph, 2013. [Online]. Available: http://www.telegraph.co.uk/news/earth/earthnews/10325531/TheBond-villain-salt-mine-where-Britains-hazardous-waste-is-stored.html

[13] Greater Manchester Waste Disposal Authority (GMWDA). Where does all your recycling go? [Online]. Available: http://www.recycleforgreatermanchester.com/recycle/where-doesit-all-go/away (2015)

[14] Department of Energy and Climate Change (DECC). UK Energy In Brief 2014. [Online]. Available: https://www.gov.uk/government/uploads/system/uploads/attachment _data/file/350941/UK_Energy_in_Brief_2014_revised.pdf (2014)

[15] J. Lepawsky, "The changing geography of global trade in electronic discards: time to rethink the e-waste problem," The Geographical Journal, 2014. [Online]. Available: http://dx.doi.org/10.1111/geoj.12077

[16] Greater Manchester Waste Disposal Authority (GMWDA). Re-use electricals. [Online]. Available: http://www.recycleforgreatermanchester.com/re-use/electricals (2015)

[17] M. Wei and L. M. Grupp, "Reliably erasing data from flash-based solid state drives," in Proceedings of the 9th USENIX Conference on File and Storage Technologies, Berkley, CA, USA, 2011, pp. 105-117.

[18] M. Kassner, "Erasing ssds: Security is an issue," Tech Republic, 2014. [Online]. Available: http://www.techrepublic.com/article/erasingssds-security-is-an-issue/

[19] A. Jones, "How much information do organizations throw away?" Computer Fraud and Security, vol. 2005 , no. 3, 2005, pp. 4 - 9. [Online]. Available: http://www.sciencedirect.com/science/article/pii/S1361372305701706

[20] E. Chung, "B.c. students buy sensitive U.S. defence data for $\$ 40$ in Africa," Canadian Broadcast Corporation (CBC), 2009. [Online]. Available: http://www.cbc.ca/news/technology/b-c-studentsbuy-sensitive-u-s-defence-data-for-40-in-africa-1.803353

[21] K. A. Asante, T. Agusa, C. A. Biney, W. A. Agyekum, M. Bello, M. Otsuka, T. Itai, S. Takahashi, and S. Tanabe, "Multi-trace element levels and arsenic speciation in urine of e-waste recycling workers from Agbogbloshie, Accra in Ghana," Science of the Total Environment, vol. 424, no. C, May 2012, pp. 63-73.

[22] K. McElvaney, "In pictures: Ghana's e-waste magnet," Al Jazeera, 2014. [Online]. Available: http://www.aljazeera.com/indepth/inpictures/2014/01/picturesghana-e-waste-mecca-2014130104740975223.html
[23] Computer Aid. Our Projects. [Online]. Available: http://www.computeraid.org/our-projects.asp (2015)

[24] R. Heeks, "Information systems and developing countries: Failure, success, and local improvisations," The Information Society, vol. 18, no. 2, 2002, pp. 101-112. [Online]. Available: http://dx.doi.org/10.1080/01972240290075039

[25] B. H. Robinson, "E-waste: An assessment of global production and environmental impacts," Science of The Total Environment, vol. 408, no. 2, 2009, pp. 183-191. [Online]. Available: http://www.sciencedirect.com/science/article/pii/S0048969709009073

[26] P. Pandey and M. Govind, "Social repercussions of e-waste management in India: a study of three informal recycling sites in delhi," International Journal of Environmental Studies, vol. 71, no. 3, 2014, pp. 241-260. [Online]. Available: http://www.tandfonline.com/doi/abs/10.1080/00207233.2014.926160

[27] O. Osibanjo and I. Nnorom, "The challenge of electronic waste (e-waste) management in developing countries," Waste Management \& Research, vol. 25, no. 6, 2007, pp. 489-501. [Online]. Available: http://wmr.sagepub.com/content/25/6/489.abstract

[28] S. Sthiannopkao and M. H. Wong, "Handling e-waste in developed and developing countries: Initiatives, practices, and consequences," Science of The Total Environment, vol. 463-464, 2013, pp. 1147 - 1153. [Online]. Available: http://www.sciencedirect.com/science/article/pii/S0048969712009217

[29] United Kingdom Environment Agency. Essex man jailed after environment agency investigation into illegal waste exports. [Online]. Available: https://www.gov.uk/government/news/waste-dealerjailed-for-16-months-after-dangerous-shipments-stopped-at-port (2014)

[30] A. Wasley, "Uk e-waste illegally dumped in ghana," 2011. [Online] Available: http://www.theguardian.com/environment/2011/may/16/ukewaste-dumped-ghana

[31] Apple Inc. Apple certified refurbished products: Canada. [Online]. Available: http://store.apple.com/uk/browse/home/specialdeals/refurbfaq_popup (2014)

[32] CBC News, "Apple's iphone recycling program expands to canada," 2014. [Online]. Available: http://www.cbc.ca/news/technology/apple-siphone-recycling-program-expands-to-canada- 1.2567210

[33] Apple Inc. Apple recycling program - recycling in canada. [Online] Available: http://www.apple.com/ca/recycling/ (2014)

[34] A. L. Deathe, E. MacDonald, and W. Amos, "E-waste management programmes and the promotion of design for the environment: Assessing canada's contributions," Review of European Community \& International Environmental Law, vol. 17, no. 3, 2008, pp. 319-334. [Online]. Available: http://dx.doi.org/10.1111/j.14679388.2008.00610.x

[35] Alberta Recycling Management Authority. About us. [Online]. Available: http://www.albertarecycling.ca/about-us (n.d.)

[36] - Collection sites in your community. [Online]. Available: http://www.albertarecycling.ca/collection-site-searchresults?city=Edmonton\&electronics=True (n.d.)

[37] City of Edmonton. E-waste (electronics) recycling. [Online]. Available: http://www.edmonton.ca/residential_neighbourhoods/garbage_recycling _waste/ewaste-electronics-recycling.aspx (2015)

[38] GEEP - Global Electric Electronic Processing. Electronics recycling. [Online]. Available: http://www.geepglobal.com/electronics-recyclingservices/electronics-recycling/ (2015)

[39] City of Edmonton. Geep electric and elec-
tronic waste recycling facility [Online]. able: http://www.edmonton.ca/programs_services/garbage_waste/geepelectric-and-electronic-waste-recycling-facility.aspx (2015)

[40] GEEP - Global Electric Electronic Processing. Electronics recycling. [Online]. Available: http://www.geepglobal.com/electronics-recyclingservices/electronics-recycling/ (2015)

[41] C. Hope. Computer disposal, donation, and recycle information. [Online]. Available: http://www.computerhope.com/disposal.htm\#donation (2015)

[42] CBC News, "Surrey recycling firm charged with exporting hazardous waste," 2013. [Online]. Avail- 
able: http://www.cbc.ca/news/canada/british-columbia/surrey-recyclingfirm-charged-with-exporting-hazardous-waste-1.1401086

[43] Recycling Council of British Columbia (RCBC). Ewaste recycling: whats really going on? [Online]. Available: http://www.rcbc.ca/resources/additional-resources-links/ewaste\#reallygoingon (2015)

[44] J. Evans, "Greenpeace says everyone should copy Apple," Computer World, 2014. [Online]. Available: http://www.computerworld.com/article/2601821/greenpeace-sayseveryone-should-copy-apple.html

[45] K. Naidoo, "Apples new green manifesto: Renewable energy is ready to become mainstream," Greenpeace.org, 2014. [Online]. Available: http://www.greenpeace.org/international/en/news/Blogs/makingwaves/ apple-earth-day/blog/49072/

[46] Corporate Watch. Veolia's dirty business: The Tovlan landfill. [Online] Available: http://www.corporatewatch.org/news/2010/jan/27/veoliasdirty-business-tovlan-landfill (2010)

[47] Global Exchange. Why target Veolia? [Online]. Available: http://globalexchange.org/economicactivism/veolia/why (2011)

[48] M. Donati, "Unilever saves 200 million by eliminating landfill waste," 2015. [Online]. Available: http://www.supplymanagement.com/news/2015/unilever-saveseu200-million-by-eliminating-landfill-waste

[49] The Restart Project. The most \#ethicalmob. [Online]. Available: http://therestartproject.org/consumption/the-most-ethicalmob/ (2014)

[50] E. Consumer, "Shopping guide to laptops, from ethical consumer," n.d. [Online]. Available: http://www.ethicalconsumer.org/buyersguides/computing/laptopsand netbooks.aspx

[51] J. Puckett, L. Byster, S. Westervelt, R. Gutierrez, S. Davis, A. Hussain, and M. Dutta, Exporting harm: The high-tech trashing of Asia. Seattle, USA: Basel Action Network, 2002.

[52] R. Widmer, H. Oswald-Krapf, D. Sinha-Khetriwal, M. Schnellmann, and H. Bni, "Global perspectives on e-waste," Environmental Impact Assessment Review, vol. 25, no. 5, 2005, pp. 436 - 458, environmental and Social Impacts of Electronic Waste Recycling. [Online]. Available: http://www.sciencedirect.com/science/article/pii/S0195925505000466

[53] D. S. Khetriwal, R. Widmer, R. Kuehr, and J. Huisman, "One weee, many species: lessons from the european experience," Waste Management \& Research, vol. 29, no. 9, 2011, pp. 954-962. [Online]. Available: http://wmr.sagepub.com/content/29/9/954.abstract

[54] F. Ongondo, I. Williams, and T. Cherrett, "How are \{WEEE\} doing? a global review of the management of electrical and electronic wastes," Waste Management, vol. 31, no. 4, 2011, pp. 714 - 730. [Online]. Available: http://www.sciencedirect.com/science/article/pii/S0956053X10005659

[55] R. Wakkary, A. Desjardins, S. Hauser, and L. Maestri, "A sustainable design fiction: Green practices," ACM Trans. Comput.-Hum. Interact., vol. 20, no. 4, Sep. 2008, pp. 23:1-23:34. [Online]. Available: http://doi.acm.org/10.1145/2494265

[56] C. Linehan, B. J. Kirman, S. Reeves, M. A. Blythe, J. G. Tanenbaum, A. Desjardins, and R. Wakkary, "Alternate endings: Using fiction to explore design futures," in CHI '14 Extended Abstracts on Human Factors in Computing Systems, ser. CHI EA '14. New York, NY, USA: ACM, 2014, pp. 45-48. [Online]. Available: http://doi.acm.org/10.1145/2559206.2560472

[57] T. Markussen and E. Knutz, "The poetics of design fiction," in Proceedings of the 6th International Conference on Designing Pleasurable Products and Interfaces, ser. DPPI '13. New York, NY, USA: ACM, 2013, pp. 231-240. [Online]. Available: http://doi.acm.org/10.1145/2513506.2513531

[58] J. Bleecker, "Design fiction: A short essay on design, science, fact and fiction," Near Future Laboratory, 2009. [Online]. Available: http://blog.nearfuturelaboratory.com/2009/03/17/design-fiction-ashort-essay-on-design-science-fact-and-fiction/

[59] S. Prost, E. Mattheiss, and M. Tscheligi, "From awareness to empowerment: Using design fiction to explore paths towards a sustainable energy future," in Proceedings of the 18th ACM Conference on Computer Supported Cooperative Work and Social Computing, ser.
CSCW '15. New York, NY, USA: ACM, 2015, pp. 1649-1658. [Online]. Available: http://doi.acm.org/10.1145/2675133.2675281

[60] D. Hales, "Design fictions an introduction and provisional taxonomy," Digital Creativity, vol. 24, no. 1, 2013, pp. 1-10. [Online]. Available: http://dx.doi.org/10.1080/14626268.2013.769453

[61] A. Dunne and F. Raby, Speculative Everything: Design, Fiction, and Social Dreaming. The MIT Press, 2013.

[62] G. Teubner, "Rights of non-humans? electronic agents and animals as new actors in politics and law," Journal of Law and Society, vol. 33, no. 4, 2006, pp. 497-521. [Online]. Available: http://dx.doi.org/10.1111/j.1467-6478.2006.00368.x

[63] A. Garland (Director), "Ex Machina," DNA Films, 2015.

[64] S. Spielberg (Director), "A.I. Artificial Intelligence," Warner Bros., 2001.

[65] S. Kubrick (Director), "2001: A Space Odyssey," Metro-GoldwynMayer (MGM), 1968.

[66] S. Ilstedt and J. Wangel, "Altering expectations: How design fictions and backcasting can leverage sustainable lifestyles," in Proceedings from DRS (Design Research Society) 2014: Design's Big Debates - Pushing the Boundaries of Design Research, Ume, Sweden, 2014. [Online]. Available: http://www.drs2014.org/en/presentations/265/

[67] P. Lin, K. Abney, and G. A. Bekey, Robot ethics: the ethical and social implications of robotics. MIT Press, 2011.

[68] T. J. Lodato and D. Loi, "Where's love in e-waste?" in Proceedings of the 13th Participatory Design Conference: Short Papers, Industry Cases, Workshop Descriptions, Doctoral Consortium Papers, and Keynote Abstracts - Volume 2, ser. PDC '14. New York, NY, USA: ACM, 2014, pp. 195-197. [Online]. Available: http://doi.acm.org/10.1145/2662155.2667198

[69] C. Remy, S. Gegenbauer, and E. M. Huang, "Bridging the theorypractice gap: Lessons and challenges of applying the attachment framework for sustainable hci design," in Proceedings of the 33rd Annual ACM Conference on Human Factors in Computing Systems, ser. CHI '15. New York, NY, USA: ACM, 2015, pp. 1305-1314. [Online]. Available: http://doi.acm.org/10.1145/2702123.2702567 